\title{
ANGPTL6 Genetic Variants Are an Underlying Cause of Familial Intracranial Aneurysms
}

Isabel C. Hostettler, MD, Benjamin O'Callaghan, MSci, Enrico Bugiardini, MD, Emer O'Connor, MD, Jana Vandrovcova, PhD, Indran Davagnanam, MD, Varinder Alg, MD, Stephen Bonner, PhD, Daniel Walsh, PhD, Diederik Bulters, FRCS, Neil Kitchen, PhD, Martin M. Brown, FRCP, Joan Grieve, MD,

David J. Werring, PhD, FRCP, and Henry Houlden, PhD FRCP, on behalf of the Genetics and Observational Subarachnoid Haemorrhage (GOSH) study investigators

Neurology ${ }^{\circledR}$ 2021;96:e947-e955. doi:10.1212/WNL.0000000000011125

\section{Abstract}

\section{Purpose}

To understand the role of the angiopoietin-like 6 gene (ANGPTL6) in intracranial aneurysms (IAs), we investigated its role in a large cohort of familial IAs.

\section{Methods}

Individuals with family history of IA were recruited to the Genetic and Observational Subarachnoid Haemorrhage (GOSH) study. The ANGPTL6 gene was sequenced using Sanger sequencing. Identified genetic variants were compared to a control population.

\section{Results}

We found 6 rare ANGPTL6 genetic variants in 9/275 individuals with a family history of IA (3.3\%) ( 5 missense mutations and 1 nonsense mutation leading to a premature stop codon), none present in controls. One of these had been previously reported: c.392A $>$ T (p.Glu131Val) on exon 2; another was very close: c.332G>A (p.Arg111His). Two further genetic variants lie within the fibrinogen-like domain of the ANGPTL6 gene, which may influence function or level of the ANGPTL6 protein. The last 2 missense mutations lie within the coiled-coil domain of the ANGPTL6 protein. All genetic variants were well conserved across species.

\section{Conclusion}

ANGPTL6 genetic variants are an important cause of IA. Defective or lack of ANGPTL6 protein is therefore an important factor in blood vessel proliferation leading to IA; dysfunction of this protein is likely to cause abnormal proliferation or weakness of vessel walls. With these data, not only do we emphasize the importance of screening familial IA cases for ANGPTL6 and other genes involved in IA, but also highlight the ANGPTL6 pathway as a potential therapeutic target.

\section{Classification of Evidence}

This is a Class III study showing some specificity of presence of the ANGPTL6 gene variant as a marker of familial intracranial aneurysms in a small subset of individuals with familial aneurysms.

\author{
Correspondence \\ Dr. Houlden \\ h.houlden@ucl.ac.uk
}

\section{MORE ONLINE}

$\rightarrow$ Class of Evidence

Criteria for rating

therapeutic and diagnostic studies

NPub.org/coe 


\section{Glossary}

aSAH = aneurysmal subarachnoid hemorrhage; ExAC = Exome Aggregation Consortium; FLD = fibrinogen-like domain; gnomAD = Genome Aggregation Database; GOSH = Genetic and Observational Subarachnoid Haemorrhage; IA = intracranial aneurysm; MAF = minor allele frequency; $\mathbf{M R C}=$ Medical Research Council; NMD = nonsense-mediated decay; SAH = subarachnoid haemorrhage; SIFT $=$ Sorting Intolerant From Tolerant; UIA = unruptured intracranial aneurysm.

Three percent of the general population harbor an unruptured intracranial aneurysm (UIA). ${ }^{1}$ Ruptured UIAs cause aneurysmal subarachnoid hemorrhage (aSAH), a devastating condition with high mortality and morbidity and great socioeconomic burden. ${ }^{2,3}$ Despite efforts to discover factors associated with aneurysm formation and rupture, little is known about mechanisms driving aneurysm formation, growth, and rupture as well as the genetic background of this disease. Some inherited disorders, such as autosomal dominant polycystic kidney disease, have been associated with increased aneurysm formation as well as rupture. ${ }^{4,5}$ Increasing evidence exists that genetic factors also play a role in intracranial aneurysm (IA) formation in patients without underlying genetic diseases. ${ }^{6,7}$

Most IAs are acquired lesions arising under hemodynamic stress and associated defective wall response. ${ }^{8}$ Disturbances in angiogenic factors can lead to changes in vessel structure and cerebral artery wall stability. Genes involved in angiogenesis have recurrently been investigated. The angiopoietin-like 6 (ANGPTL6) gene is a protein-coding gene belonging to the ANGPTL family, which has been associated with regulatory capacities in angiogenesis. ${ }^{9-11}$ ANGPTL6 has been identified as a circulating proangiogenic factor increasing endothelial permeability. ${ }^{9,12} \mathrm{~A}$ recent publication found significant enrichment in rare coding variants within ANGPTL6 in patients with familial IA. ${ }^{13}$ They demonstrated a reduction of $50 \%$ in the serum concentration of ANGPTL6 in individuals heterozygous for c. $1378 \mathrm{~A}>\mathrm{T} .{ }^{13}$

We aimed to externally validate the previous findings, to search for additional rare variants, and to evaluate the rate of rare variants in a large cohort of individuals with family history of IA.

\section{Methods}

\section{Patient Selection}

For the main analysis, we included patients with available DNA and familial IA where at least 1 affected first- or second-degree relative had IA and was recruited into the Genetic and Observational Subarachnoid Haemorrhage (GOSH) study to evaluate whether previously reported variants would be detected in those with only 1 affected first- or second-degree family member as well (figure 1). Only 1 patient had only 1 affected first- or second-degree relative. Patients with unruptured or ruptured IA could be included in this study. We compare patients with familial IA and the rest of the cohort in table 1 in order to highlight differences. A description of the whole cohort is published elsewhere. ${ }^{14}$ Written informed consent was obtained from all participants, or in case of lack of capacity, from a representative. We did not include patients with perimesencephalic subarachnoid hemorrhage (SAH) (defined by blood distribution mainly or only in the cisterns around the midbrain), absence of intracranial aneurysm, or SAH due to trauma as well as mycotic aneurysms. None of the patients included had been diagnosed with Ehlers-Danlos syndrome, Marfan syndrome, or polycystic kidney disease. IA was confirmed on $\mathrm{CT} /$ magnetic resonance angiography or digital subtraction angiography. Because the primary aim of this study was to replicate the association between IA and identifier variants in ANGPTL6, and genetic data from affected/unaffected relatives were not collected with the exception of a mother and daughter pair, segregation analysis was not performed.

The study was approved by the corresponding ethics committee (reference 09/H0716/54).

We used brain biopsy controls from our own laboratory as well as Medical Research Council (MRC) brain exome controls, excluding individuals with known previous stroke $(n=59)$, to compare the frequency of rare genetic variants found in cases with a control cohort.

The primary research goal is to externally validate and evaluate additional rare variants in the ANGTL6 gene. This is a Class III evidence study.

\section{Sanger Sequencing}

We extracted genomic DNA and performed PCR to amplify exons 2-6 of the ANGPTL6 gene followed by Sanger sequencing. Primer sequences can be provided upon request. We cleaned up the PCR product using Exo-Fast, before performing dye-terminator sequencing PCR with BigDye Terminator v3.1 (Thermo Fisher). The sequencing PCR product was cleaned using Sephadex (Sigma Aldrich) before being loaded onto the AB1 3730xl genetic analyzer (Applied Biosystems). We used SeqScape v.3.0 software (Applied Biosystems) for sequence analysis.

In accordance with the previous publication, we filtered out variants with a minor allele frequency (MAF) higher than 1\% in the Genome Aggregation Database (gnomAD), v2.1.1. ${ }^{13}$ 
Figure 1 Patients and Controls Selection Flow Diagram

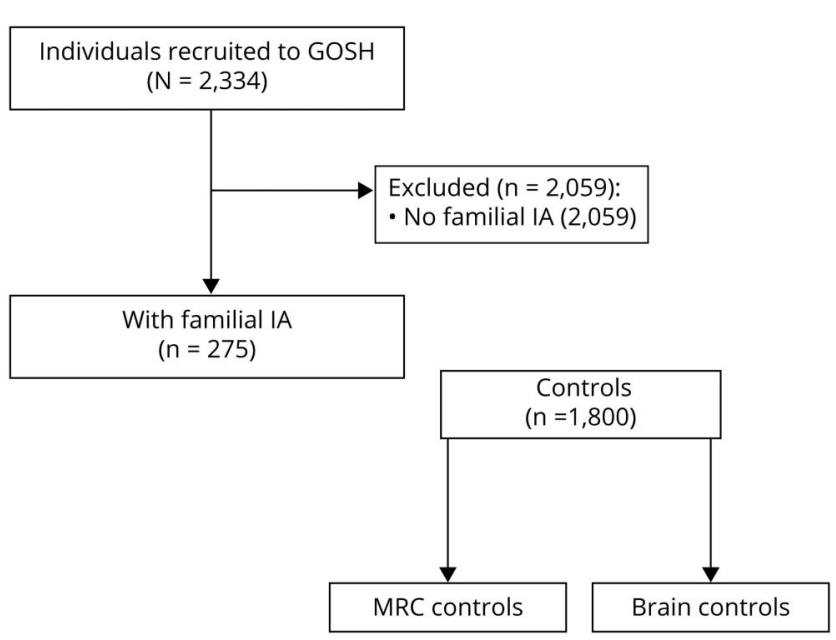

GOSH = Genetic and Observational Subarachnoid Haemorrhage; $\mathrm{IA}=$ intracranial aneurysm; MRC = Medical Research Council.

\section{Brain Bank Neuropathologically Normal and MRC Controls}

Libraries for brain biopsy controls were generated using TruSeq Exome Enrichment Kit (Illumina), according to the manufacturer's protocol, and sequenced on Illumina HiSeq, generating $150 \mathrm{bp}$ paired end reads. The average coverage obtained was $36 \times$. Reads were aligned to
GRCh37 using Novoalign and variants were called using GATK HaplotypeCaller. Whole exome sequencing data from the MRC brain bank samples were obtained from EGA (EGAS00001001599), mainly sequenced using the Illumina HiSeq 2000 array (ega-archive.org/).

We compared the MAF of rare variants in our cases with our in-house brain control exomes, the MRC controls, and data available on population databases, specifically gnom $A D$ (gnomad.broadinstitute.org) and Exome Aggregation Consortium (ExAC) (exac.broadinstitute.org) (figure 2). ${ }^{15} \mathrm{We}$ then further checked the estimated effect of the according rare mutation using different computation predictive programs. As functional prediction scores, we used PolyPhen-2 and Sorting Intolerant From Tolerant (SIFT). These are used to help interpret the sequence variant.

\section{Standard Protocol Approvals, Registrations, and Patient Consents}

This study received approval from the ethical standards committee on human experimentation for any experiments using human subjects (UKCRN ID-7512, 09/H0716/54).

\section{Data Availability}

Anonymized data will be shared by request from any qualified investigator. EGAS00001001599 can be requested from the European Genome-Phenome Archive.

Table 1 Baseline Characteristics and Risk Factors

\begin{tabular}{|c|c|c|c|c|c|c|}
\hline & $\begin{array}{l}\text { Familial aneurysms, } \\
n=275\end{array}$ & $\begin{array}{l}\text { Nonfamilial aneurysms, } \\
n=2059\end{array}$ & $p$ Value & UIA, $n=90$ & aSAH, $\mathbf{n}=185$ & $p$ Value \\
\hline Age, y & $51.8(12.6)$ & $54.5(12.7)$ & 0.001 & $53.6(10.9)$ & $51(13.3)$ & 0.1 \\
\hline Female sex & 217 (78.9) & $1,423(69.1)$ & 0.001 & 75 (83.3) & $142(76.8)$ & 0.21 \\
\hline Current smoker & $108(39.3)$ & $885(43)$ & 0.24 & $26(28.9)$ & $82(44.3)$ & 0.02 \\
\hline Current drinker & $176(64)$ & $1,384(67.2)$ & 0.29 & $52(58.8)$ & $124(67)$ & 0.14 \\
\hline \multicolumn{7}{|l|}{ PMH } \\
\hline HTN & $98(35.6)$ & $725(35.2)$ & 0.89 & $38(42.2)$ & $60(32.4)$ & 0.11 \\
\hline Hypercholesterolemia & $60(21.8)$ & $508(24.7)$ & 0.3 & $33(36.7)$ & $27(14.6)$ & $<0.001$ \\
\hline DM & $6(2.2)$ & $102(5)$ & 0.05 & $2(2.2)$ & $4(2.2)$ & 0.97 \\
\hline OAC & $22(8)$ & $96(4.7)$ & 0.02 & $4(4.44)$ & $18(9.7)$ & 0.14 \\
\hline Antiplatelets & $33(12)$ & $271(13.2)$ & 0.59 & $19(21.19)$ & $14(7.6)$ & 0.002 \\
\hline Statins & $48(17.5)$ & $417(20.3)$ & 0.28 & $26(28.9)$ & $22(11.9)$ & 0.001 \\
\hline Anti-HTN & $81(29.5)$ & $599(29.1)$ & 0.9 & $32(35.6)$ & $49(26.5)$ & 0.12 \\
\hline Previous SAH & $4(1.5)$ & $36(1.8)$ & 0.73 & 0 & $4(2.2)$ & omit \\
\hline
\end{tabular}

Abbreviations: anti-HTN = antihypertensive medication; $\mathrm{aSAH}=$ aneurysmal subarachnoid hemorrhage; DM = diabetes mellitus; $\mathrm{HTN}=$ hypertension; $\mathrm{OAC}=$ oral anticoagulation; $\mathrm{PMH}$ = past medical history; $\mathrm{SAH}=$ subarachnoid hemorrhage; UIA = unruptured intracranial aneurysm.

Values are mean (SD) or $\mathrm{n}(\%)$. 


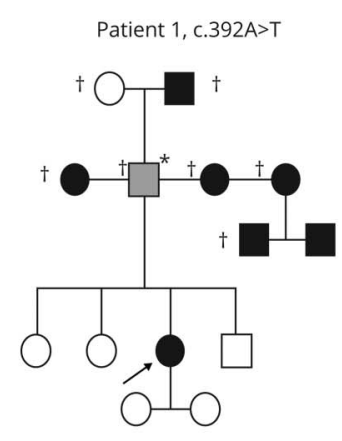

Patient 4, c.1073G >A

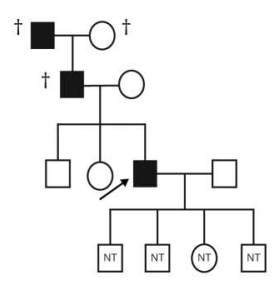

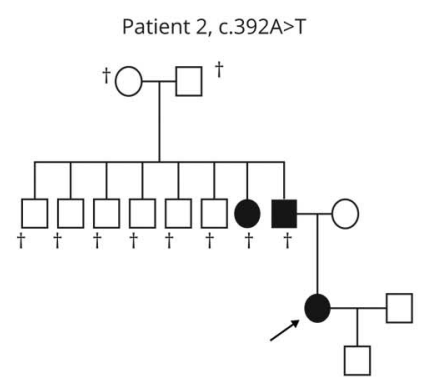

Patient 5, c.243G>C

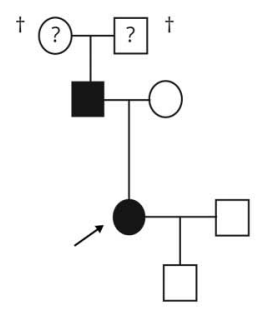

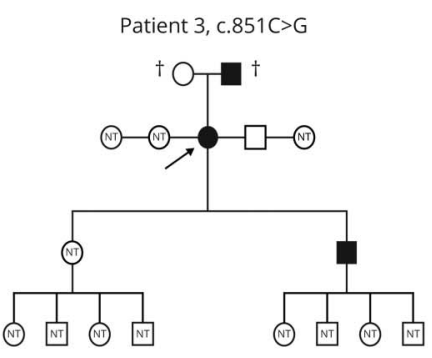

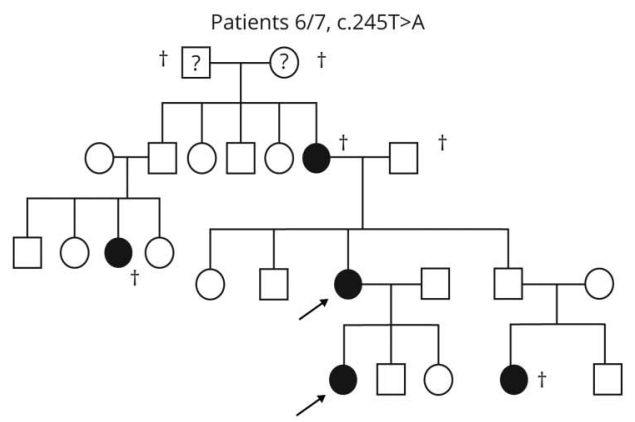

\section{Results}

We included 275 patients with family history of IA. Of these 275 patients, 185 (67.3\%) had had an aSAH. Baseline characteristics and risk factors are summarized in table 1. Comparing familial with sporadic IA, we found that individuals with familial IA were, as expected, younger than their nonfamilial equivalent. Interestingly, individuals with familial IA were more frequently female, and were more frequently on oral anticoagulation, but not on antiplatelets. We did not find a difference in hypertension. In our cohort of patients with family history of IA, $9 / 275$ individuals (3.3\%) harbored a rare $(<0.01 \%$ gnomAD MAF) exonic mutation (figure 2 for the family trees of $7 / 9$ individuals).

We found a total of 13 different nucleotide changes in ANGPTL6. Four of these changes resulted in the synonymous amino acid and 3 had a gnomAD MAF above $1 \%$ (2 of which were also present in the control group) and were consequently not considered. In the remaining 6 rare genetic variants, we noted 5 different missense mutations and 1 nonsense mutation (table 2). None of these rare genetic variants was present in our control population of 1,800 individuals. Figure 3 demonstrates imaging studies of the aneurysms of 3 of our patients.

\section{Previously Reported Variants and Associated Variants}

We replicated the previous finding of c.392A $>\mathrm{T}$ (p.Glu131Val), which has previously been reported as deleterious as per SIFT. ${ }^{13}$ In our cohort, this mutation was present in 2 individuals (MAF 0.004; figure 2, individuals 1 and 2). It was not present in our control population or the ExAC database, but it was present in gnomAD population controls, with a MAF of 0.001. p.Glu131Val is moderately conserved across species, and lies within the linker region between the coiled-coil and fibrinogen-like domains (FLD), but no functional role has been described (figures 4 and 5). We found a previously unreported mutation very close to c.392A $>\mathrm{T}$ : c.332G $>$ A (p.Arg111His) in 1 individual (MAF 0.002; figure 2 , individual 8 ). This variant was not present in our control population or ExAC or gnomAD databases and is estimated to be deleterious as per SIFT. The mutation lies within the coiled-coil domain, which is important for the function of angiopoietin-like proteins. ${ }^{16}$ p. Arg111His is moderately conserved across species but no functional role for this specific residue has been described.

\section{Novel Rare Variants}

In addition to c.332G >A (p.Arg111His), which lies in close proximity to the previously reported c.392A $>\mathrm{T}$ (p.Glu131Val), we found 4 additional rare genetic variants that have not been reported. Most notably, we found a c. $851 \mathrm{C}>\mathrm{G}$ (p.Ser284*) nonsense mutation leading to a premature stop codon in 1 individual (MAF 0.002; figure 2, individual 3). This variant was not present in our own control cohort; however, it was present in ExAC and gnomAD, with MAF of 0.0004 and 0.0005 , respectively. This mutation occurs in Ex4 and is predicted to lead to nonsense-mediated decay (NMD) or production of a truncated protein lacking the majority of the FLD. This stop-gain mutation has been described to result in complete loss of secretion of ANGPTL6 protein in cells. ${ }^{17}$ It is moderately conserved across species. 
Table 2 Rare Nonsynonymous Variants in the ANGPTL6 Gene in Patients With Familial Intracranial Aneurysm

\begin{tabular}{|c|c|c|c|c|c|c|c|c|c|c|}
\hline $\begin{array}{l}\text { Nucleotide } \\
\text { change }\end{array}$ & Exon & $\begin{array}{l}\text { Protein } \\
\text { consequence }\end{array}$ & dbSNP & Het & Hom & $\begin{array}{l}\text { MAF } \\
(n=500)\end{array}$ & $\begin{array}{l}\text { EXAC } \\
\text { MAF }\end{array}$ & $\begin{array}{l}\text { GnomAD } \\
\text { MAF }\end{array}$ & SIFT & PolyPhen \\
\hline c. $243 G>C$ & Ex2 & p. $81 R>S$ & rs1166038416 & 1 & 0 & 0.0018 & NP & 0.00011 & $\begin{array}{l}\text { Tolerated } \\
(0.74)\end{array}$ & Benign (0.025) \\
\hline c. $245 T>A$ & Ex2 & p.82L $>Q$ & rs979714863 & 3 & 0 & 0.0055 & NP & 0.000068 & $\begin{array}{l}\text { Tolerated } \\
(0.25)\end{array}$ & Benign (0.003) \\
\hline c. $332 \mathrm{G}>\mathrm{A}$ & Ex2 & p.111R $>\mathrm{H}$ & rs1310828976 & 1 & 0 & 0.0018 & NP & NP & $\begin{array}{l}\text { Deleterious } \\
(0.04)\end{array}$ & Benign (0.254) \\
\hline$c .392 A>T^{13}$ & Ex2 & p.131E>V & rs576667683 & 2 & 0 & 0.0036 & $\mathrm{NP}$ & 0.0015 & $\begin{array}{l}\text { Deleterious } \\
\text { (0) }\end{array}$ & $\begin{array}{l}\text { possibly } \\
\text { damaging (0.724) }\end{array}$ \\
\hline$c .851 \mathrm{C}>\mathrm{G}$ & Ex4 & p.284S> & rs201622589 & 1 & 0 & 0.0018 & 0.0004 & 0.00045 & & \\
\hline c. $1073 \mathrm{G}>\mathrm{A}$ & Ex5 & p. $358 \mathrm{R}>\mathrm{H}$ & rs779399477 & 1 & 0 & 0.0018 & 0.000025 & 0.000031 & $\begin{array}{l}\text { Tolerated } \\
(0.33)\end{array}$ & Benign (0.013) \\
\hline
\end{tabular}

Abbreviations: Ex = Exon; ExAC = Exome Aggregation Consortium; gnomAD = Genome Aggregation Database; Het $=$ Heterozygous; Hom $=$ Homozygous; $\mathrm{MAF}=$ minor allele frequency; NP = not present; SIFT = Sorting Intolerant From Tolerant.

Another mutation present in our cases lying within the FLD of the ANGPTL6 gene is c.1073G>A (p.Arg358His), which was again present in 1 individual (MAF 0.002; figure 2, individual 4). This variant was not present in our control group but present in ExAC and gnomAD databases with low MAF of 0.00002 and 0.00003 , respectively. p.Arg358His lies within the FLD, which is also important for the activity of angiopoietin-like proteins and is moderately conserved across species, but no functional role of this specific residue has been described. $^{16}$

Finally, we found 2 further missense mutations: c.243G $>C$ (p.Arg81Ser) in 1 individual (MAF 0.002; figure 2, individual 5) and c.245T >A (p.Gln82Leu) in 3 individuals (MAF 0.005; figure 2, individuals 6 and 7; family tree for the third individual not available). Interestingly, 2 of these individuals were related (mother and daughter). These 2 genetic variants affect adjacent residues, and both lie within the coiled-coil domain of ANGPTL6. Both amino acids are moderately conserved across species but for neither of them has a functional role been described.

\section{Discussion}

We present a study of the ANGPTL6 gene in a large cohort with family history of IA replicating 1 of the previously presented variants: c.392.A $>\mathrm{T}$ (p.Glu131Val) in the linker region. In addition, we found c.332G $>A$ (p.Arg111His) located very close to this previously described mutation within the coiled-coiled domain. We also found 2 genetic variants in the FLD of the ANGPTL6 gene, 1 being a nonsense mutation that leads to a stop-gain, which has been described to result in complete loss of ANGPTL6 secretion. None of the genetic variants presented here was found in our 1,800 controls.
Most likely due to the continuous expansion and sometimes merging of databases such as gnomAD and ExAC, some of the previously described variants have now also been described in these control populations. We did not replicate any of the other described variants but found 4 additional ones. All of the rare variants reported here were much rarer in the analyzed control populations, if present at all.

Our study provides additional insight building on the previous study on ANGPTL6 in individuals with familial IA. ${ }^{13}$ The c. $851 \mathrm{C}>\mathrm{G}\left(\mathrm{p} . \mathrm{Ser} 284^{*}\right)$ stop-gain mutation we identified lies in ANGPTL6 Ex4 and likely results in NMD of the mutant transcript, which could contribute to haploinsufficiency. It is also possible that this mutation leads to the expression of a truncated protein lacking the majority of the FLD, reducing ANGPTL6 protein function or stability. In fact, a previous study reported this variant leads to a complete loss of secretion of the ANGPTL6 protein in cells. ${ }^{17}$ The actual effect of reduced ANGPTL6 secretion remains unknown and warrants further investigation. We also identify novel genetic variants in the FLD and coiled-coil domain of ANGPTL6, which might be impairing the proangiogenic function or overall stability of the protein. ${ }^{16}$ Although no function specific to ANGPTL6 has been established, the FLD is suggested to regulate angiogenic activities. ${ }^{10,16}$ The same is true for the coiledcoil domain. Several functions of this domain have been reported, including activity in polymer formation, molecular recognition, cytoskeletal regulation, and $\mathrm{pH}$ sensing. ${ }^{18}$ Based on the information available, a dominant negative mechanism cannot be conclusively ruled out, especially in missense changes. A potential mechanism could be that the mutation alters the protein structural binding, preventing ANGPTL6 signaling. The ANGPTL family also regulates lipid and glucose metabolism and by doing so indirectly 

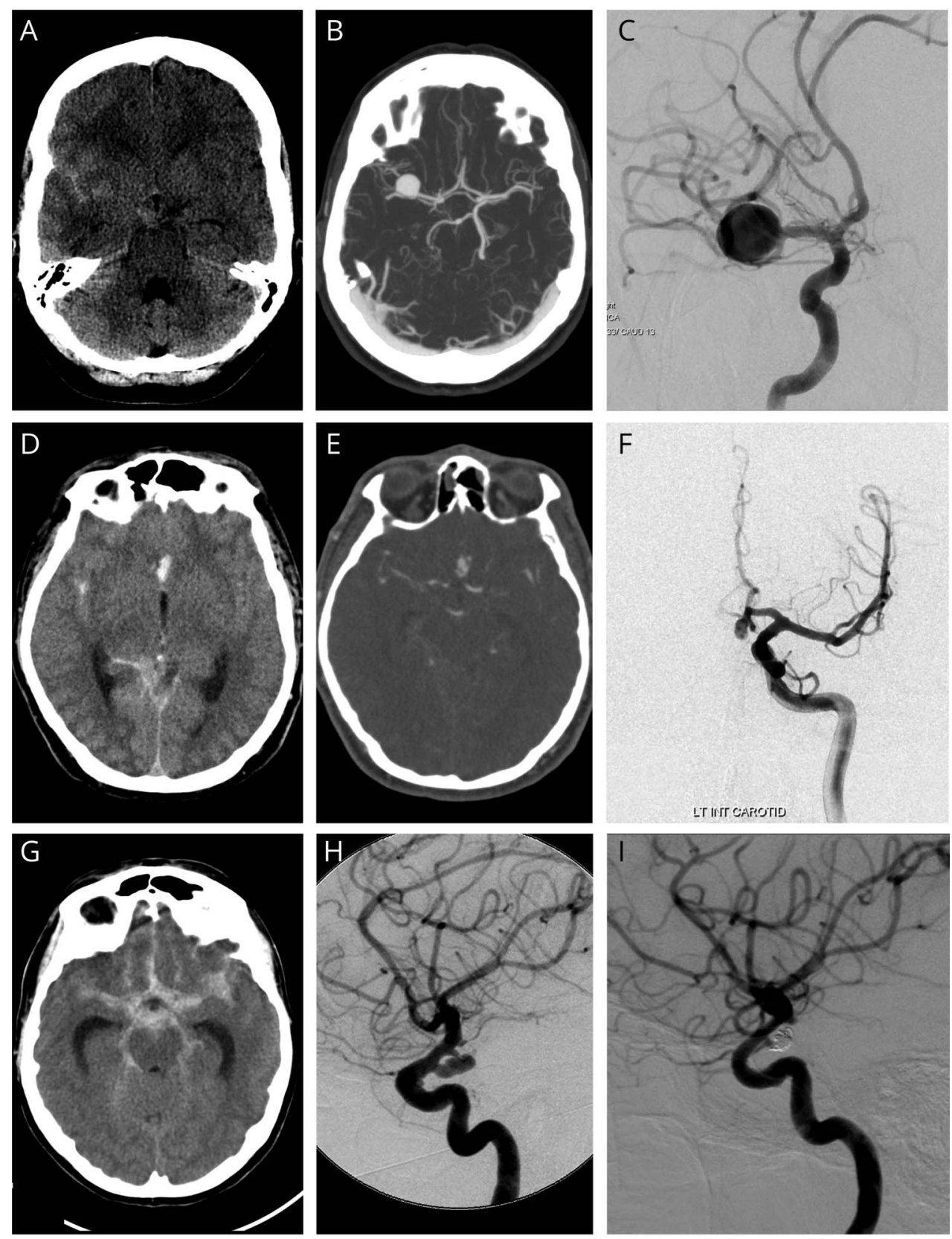

Patient 1: a 48-year-old woman presenting with subarachnoid hemorrhage (SAH) within the right sylvian fissure and suprasellar cistern on the axial noncontrast CT examination (A), from a large right terminal M1 segment right middle cerebral artery aneurysm demonstrated on a maximal intensity projection axial CT angiogram (B), and an oblique view of a selective injection into the right internal carotid artery on digital subtraction cerebral angiography (C). Patient 2: a 41-year-old man presenting with $\mathrm{SAH}$ within the right sylvian fissure, anterior interhemispheric fissure, and right quadrigeminal cistern on the axial noncontrast $C T$ examination (D), from an A1-A2 junction aneurysm of the left anterior cerebral artery demonstrated on axial CT angiography (E), and a Towne projection from the selective injection of the left internal carotid artery on digital subtraction cerebral angiography (F). Patient 3: a 57-year-old woman presenting with extensive SAH within the sylvian fissures, anterior interhemispheric fissure, as well as the perimesencephalic and ambient cisterns on the axial noncontrast CT examination $(G)$, and from a posterior communicating segment aneurysm of the left internal carotid artery demonstrated on the lateral projection from the selective injection of the left internal carotid artery on digital subtraction cerebral angiography pre-(H) and post- (I) coil embolization with satisfactory exclusion from the arterial circulation. influences risk factors for IA formation such as hypertension. ${ }^{19-22}$

As Bourcier et al. ${ }^{13}$ hypothesized, individuals with rare variants in the ANGPTL6 gene might require additional factors in order to trigger the development of IA. Therefore, heterozygous ANGPTL6 genetic variants might only exhibit a deleterious effect in combination with certain risk factors such as high blood pressure. Other genes have also been previously reported to play a role in familial IA, such as ADAMST15 and PCNT. ADAMST15 has been shown to be significantly aggregated in families with $\mathrm{IA}^{23}$ It might be associated with IA formation through abnormal transcription of metalloproteinases. $^{24}$ Two rare variants of the PCNT gene have been found in familial IA cases. ${ }^{25}$ Deletions and mutations of this gene cause a type of dwarfism associated with IA in up to $20 \%$. $^{25}$ This indicates the genetic complexity of this disease.

Our study has strengths: we present a large cohort of individuals with family history of IA sequenced using Sanger sequencing. Sanger sequencing remains the gold standard for mutation confirmation. Concordance between Sanger sequencing and whole-exome sequencing has been reported to be $97.3 \%$. $^{26}$ This allowed us to check the variants found in our cases in a control population sequenced by whole-exome 
Figure 4 Multiple Alignment Showing Moderate Conservation Across Species and ANGPTL6 Homolog of the Residues Affected by the Variants Identified in our Cohort (Variants Highlighted in Yellow)

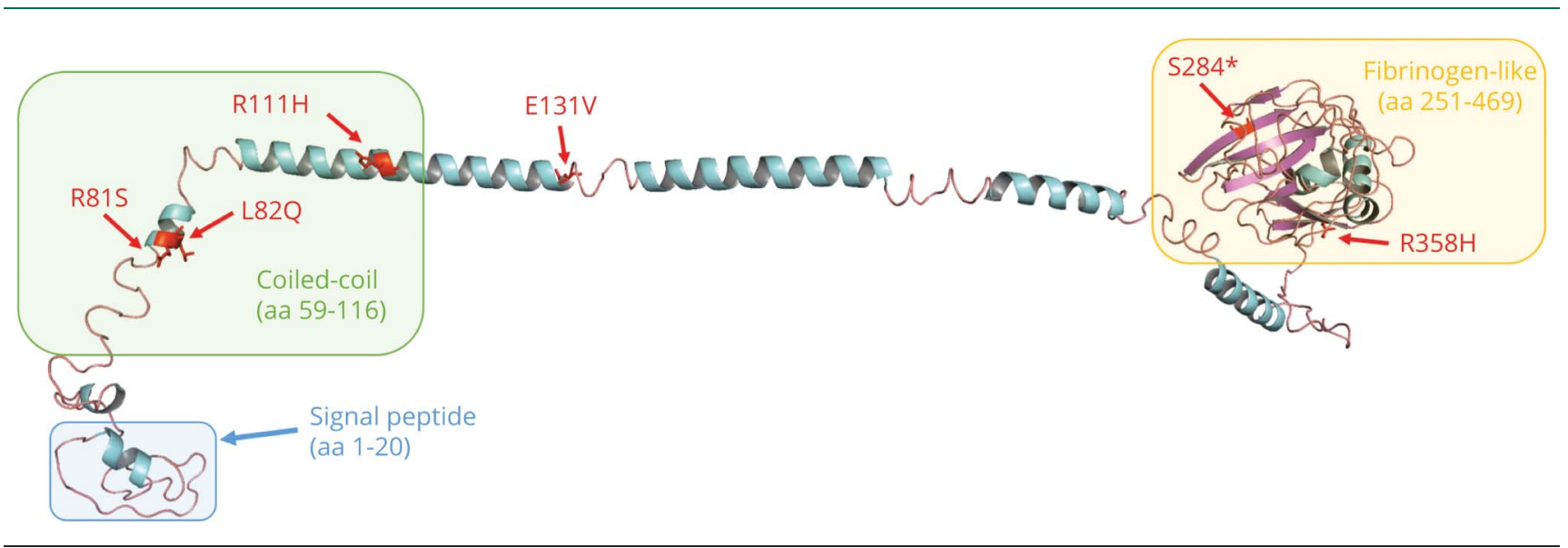

sequencing. None of the rare genetic variants found in our cases were present in our own control dataset; if the genetic variants were present in the gnomAD and ExAC control populations, they were significantly rarer, reducing the likelihood of winner's curse.

Our study has limitations: we did not sequence affected or unaffected family members (expect for 2 individuals who were related) as DNA for family members was not available and our aim was to externally validate the previous results of 4 rare coding variants within the ANGPTL6 gene; information and DNA for relatives were generally not collected as part of the GOSH study. This would be especially of interest as 1 variant was present in both mother and daughter, indicating a potential familial clustering. We included patients with only 1 affected second-degree relative not fulfilling the classical criteria of familial IA. We do not believe that this limits our results as none of the patients harboring a rare variant only had 1 affected second-degree relative. In addition, we were not able to obtain the family trees in 2 individuals; 1 was deceased (c.245T>A; p.Gln82Leu) and the other was not contactable (c.332G>A; p.Arg111His). We therefore cannot make any statements about penetrance in our population. Although we cannot make any statements about penetrance and we refrained from burden analysis due to cases and controls not having been sequenced with the same method, we demonstrated that the rare genetic variants found in our cases are far less frequent or absent in the considered control cohorts. Therefore, a genetic contribution to this disease, including by rare variant in the ANGPTL6 gene, is highly likely.

We replicated some of the previously reported genetic variants in the ANGPTL6 gene in a large cohort of individuals with family history of IA. Novel found genetic variants support that ANGPTL6 loss of function might be a genetic risk factor influencing IA development. These findings remain to be confirmed in an independent cohort. The function of the ANGPTL6 gene needs to be evaluated. It might offer a target

Figure 5 Homology Model of Human ANGPTL6 Protein and Respective Location of the Rare Variants Identified in This Study

\begin{tabular}{|c|c|c|}
\hline & R81, L82 & E131 \\
\hline ANGPTL6 HOMO SAPIENS (HUMAN) & LRMRVGRHEELLRELQRLAAADGAVAGEVRALRKESRGLSARLGQLRAQL & HEAGPGAGPGADLG----AEPAAALALSLEPESDH \\
\hline ANGPTL6 PAN TROGLODYTES (CHIMPANZEE) & LRMRVGRHEELLRELQRLAAADGAVAGEVRALRKESRGLSARLGQLRAQL & HEAGPGAGPGADLGAEPAAEPAAALALSLEPESDH \\
\hline ANGPT16 MUS MUSCULUS (MOUSE) & LRMRLGRHEELLRALQRRAAEGGALADEVRALREHSLTLNTRLGQLRAQL & 2EARAEP----DLG----AEPAAALGLSLEPESDH \\
\hline ANGPT16 RATTUS NORVEGICUS (RAT) & LRMRLGRHEELLRALQRRAAEGGALAGEVRALREHSLTLNTRLGQLRAQL & 2EAGAEP----DLG----AEPAAALGLSLEPESDH \\
\hline ANGPTL6 BOS TAURAS (COW) & LRVRVSRHEELLRELQRLATADGAVAGEVRALRKESRGLSARLGQLRAQL & HEAGPGAAPS--PG----AEPASALALSLEPESDH \\
\hline ANGPTL6 CANIS LUPUS FAMILIARIS (DOG) & LRMRVGRHEELLRELQRLAAADGAVAGEVRALRKESRGLSARLGQLRAQL & HEAGPGAGPG--PG----AEPAALLALSLEPESDY \\
\hline \multirow[t]{2}{*}{ ANGPT16 DANIO RERIO (ZEBRAFISH) } & LRALLERQQDQLDQMRGRLEEEGTLASEMRILRRESVNMNARIAQLYAQLI & SEIIQKKEQV-----------EEQRRRVEPESDW \\
\hline & S284 & R358 \\
\hline ANGPTL6 HOMO SAPIENS (HUMAN) & GRHVVSVWCEQQLEGGGWTVIQRRQDGSVNFFTTWQHYKAGFGRPDGEYWI & GLEPVYQLTSRGDHELLVLLEDWGGRGARAHYDGF \\
\hline ANGPTL6 PAN TROGLODYTES (CHIMPANZEE) & GRHVVSVWCEQQLEGGGWTVIQRRQDGSVNFFTTWQHYKAGFGRPDGEYWI & GLEPVYQLTSRGDHELLVLLEDWGGRGARAHYDGF \\
\hline ANGPT16 MUS MUSCULUS (MOUSE) & GRRVVAVWCEQQQEGGGWTVIQRRQDGSVNFFTNWQHYKAGFGRPEGEYWI & GLEPVHQVTSRGDHELLILLEDWGGRAARAHYDSF \\
\hline ANGPT16 RATTUS NORVEGICUS (RAT) & GRRVVPVWCEQQQEGGGWTVIQRRQDGSVNFFTNWQHYKVGFGRPDGEYWI & GLEPVHQVTSRGDHELLILLEDWGGRGARAHYDSF \\
\hline ANGPTL6 BOS TAURAS (COW) & 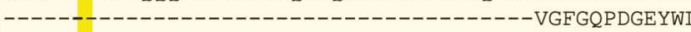 & GLEPVHQLTSRGDHELLVLLEDWGGRGARAHYDGF \\
\hline ANGPTL6 CANIS LUPUS FAMILIARIS (DOG) & GRHVVSVWCEQQLEGGGWTVIQRRQDGSVNFFTTWQHYKVGFGQPDGEYWI & GLEPVHQLTSRGDHELLVLLEDWGGRGARAHYDGF \\
\hline ANGPT16 DANIO RERIO (ZEBRAFISH) & TNRLLQAWCDQSRAQGGWTVIQRRQDGSVNFFRTWDQYKQGFGNLDGEYWI & GLEHLYWLTSQATYKLRVAMEDWQGRQVYAEYDSF \\
\hline
\end{tabular}

ANGPLTL6 homology model created using Phyre ${ }^{27}$ and human fibrinogen beta chain (PDB ID: $3 G$ GG) as the structural template. ${ }^{28}$ Three recognizable domains are present: signal peptide (blue), coiled-coil domain (green), and fibrinogen-like domain (yellow). 
for screening familial IA cases for ANGPTL6 as well as other genes involved in IA, but also highlights the ANGPTL6 pathway as a potential therapeutic target.

\section{Acknowledgment}

The authors thank the NIHR Clinical Research Network Practitioners, the investigators at participating centers, and the patients.

\section{Study Funding}

The GOSH study is funded by the Stroke Association. This work was partly undertaken at UCLH/UCL, which received a proportion of funding from the Department of Health's NIHR Biomedical Research Centres funding scheme. These funding bodies had no direct involvement in this study.

\section{Disclosure}

Isabel C. Hostettler and Henry Houlden received funding from the Alzheimer Research UK and Dunhill Medical Trust Foundation. Duncan Wilson and David J. Werring received funding from the Stroke Foundation/British Heart Foundation. Benjamin O'Callaghan, Enrico Bugiardini, Emer O'Connor, Jana Vandrovcova, Indran Davagnanam, Varinder Alg, Stephen Bonner, Daniel Walsh, Diederik Bulters, Neil Kitchen, Martin M. Brown, and Joan Grieve report no disclosures. Go to Neurology.org/ $\mathrm{N}$ for full disclosures.

\section{Publication History}

Received by Neurology January 25, 2020. Accepted in final form October 8, 2020.

Appendix 1 Authors

\begin{tabular}{|c|c|c|}
\hline Name & Location & Contribution \\
\hline $\begin{array}{l}\text { Isabel C. } \\
\text { Hostettler, } \\
\text { MD }\end{array}$ & $\begin{array}{l}\text { Stroke Research Centre, } \\
\text { University College } \\
\text { London, Institute of } \\
\text { Neurology, UK }\end{array}$ & $\begin{array}{l}\text { Designed and } \\
\text { conceptualized study, } \\
\text { acquisition of data, } \\
\text { analyzed the data, drafted } \\
\text { the manuscript, revised } \\
\text { the manuscript }\end{array}$ \\
\hline $\begin{array}{l}\text { Benjamin } \\
\text { O'Callaghan, } \\
\text { MSci }\end{array}$ & $\begin{array}{l}\text { Neurogenetics } \\
\text { Laboratory, The National } \\
\text { Hospital of Neurology and } \\
\text { Neurosurgery, London, } \\
\text { UK }\end{array}$ & $\begin{array}{l}\text { Contributed to the } \\
\text { laboratory work, analyzed } \\
\text { the data, drafted the } \\
\text { manuscript, revised the } \\
\text { manuscript }\end{array}$ \\
\hline $\begin{array}{l}\text { Enrico } \\
\text { Bugiardini, } \\
\text { MD }\end{array}$ & $\begin{array}{l}\text { Neurogenetics } \\
\text { Laboratory, The National } \\
\text { Hospital of Neurology and } \\
\text { Neurosurgery, London, } \\
\text { UK }\end{array}$ & $\begin{array}{l}\text { Contributed to the } \\
\text { laboratory work, analyzed } \\
\text { the data, drafted the } \\
\text { manuscript, revised the } \\
\text { manuscript }\end{array}$ \\
\hline $\begin{array}{l}\text { Emer } \\
\text { O'Connor, MD }\end{array}$ & $\begin{array}{l}\text { Neurogenetics } \\
\text { Laboratory, The National } \\
\text { Hospital of Neurology and } \\
\text { Neurosurgery, London, } \\
\text { UK }\end{array}$ & $\begin{array}{l}\text { Contributed to the } \\
\text { laboratory work, analyzed } \\
\text { the data, drafted the } \\
\text { manuscript, revised the } \\
\text { manuscript }\end{array}$ \\
\hline $\begin{array}{l}\text { Jana } \\
\text { Vandrovcova, } \\
\text { PhD }\end{array}$ & $\begin{array}{l}\text { Department of } \\
\text { Neuromuscular } \\
\text { Disorders, UCL Institute of } \\
\text { Neurology, Queen } \\
\text { Square, London, UK }\end{array}$ & $\begin{array}{l}\text { Analyzed the data, } \\
\text { interpreted the data, } \\
\text { revised the manuscript for } \\
\text { intellectual content }\end{array}$ \\
\hline
\end{tabular}

Appendix 1 (continued)

\begin{tabular}{|c|c|c|}
\hline Name & Location & Contribution \\
\hline $\begin{array}{l}\text { Indran } \\
\text { Davagnanam }\end{array}$ & $\begin{array}{l}\text { Department of } \\
\text { Neuroradiology, The } \\
\text { National Hospital for } \\
\text { Neurology and } \\
\text { Neurosurgery, University } \\
\text { College London Hospitals } \\
\text { NHS Foundation Trust, } \\
\text { Queen Square, UK }\end{array}$ & $\begin{array}{l}\text { Analyzed the data, revised } \\
\text { the manuscript for } \\
\text { intellectual content }\end{array}$ \\
\hline $\begin{array}{l}\text { Varinder Alg, } \\
\text { MD }\end{array}$ & $\begin{array}{l}\text { Stroke Research Centre, } \\
\text { University College } \\
\text { London, Institute of } \\
\text { Neurology, UK }\end{array}$ & $\begin{array}{l}\text { Acquisition of data, } \\
\text { revised the manuscript for } \\
\text { intellectual content }\end{array}$ \\
\hline $\begin{array}{l}\text { Stephen } \\
\text { Bonner, PhD }\end{array}$ & $\begin{array}{l}\text { Department of } \\
\text { Anaesthesia, The James } \\
\text { Cook University Hospital, } \\
\text { Middlesbrough, UK }\end{array}$ & $\begin{array}{l}\text { Acquisition of data, } \\
\text { revised the manuscript for } \\
\text { intellectual content }\end{array}$ \\
\hline $\begin{array}{l}\text { Daniel Walsh, } \\
\text { PhD }\end{array}$ & $\begin{array}{l}\text { Department of } \\
\text { Neurosurgery, King's } \\
\text { College Hospital NHS } \\
\text { Foundation Trust, } \\
\text { London, UK }\end{array}$ & $\begin{array}{l}\text { Acquisition of data, } \\
\text { revised the manuscript for } \\
\text { intellectual content }\end{array}$ \\
\hline $\begin{array}{l}\text { Diederik } \\
\text { Bulters, FRCS }\end{array}$ & $\begin{array}{l}\text { Department of } \\
\text { Neurosurgery, University } \\
\text { Hospital Southampton } \\
\text { NHS Foundation Trust, UK }\end{array}$ & $\begin{array}{l}\text { Acquisition of data, } \\
\text { revised the manuscript for } \\
\text { intellectual content }\end{array}$ \\
\hline $\begin{array}{l}\text { Neil Kitchen, } \\
\text { PhD }\end{array}$ & $\begin{array}{l}\text { Department of } \\
\text { Neurosurgery, The } \\
\text { National Hospital of } \\
\text { Neurology and } \\
\text { Neurosurgery, London, } \\
\text { UK }\end{array}$ & $\begin{array}{l}\text { Acquisition of data, } \\
\text { revised the manuscript for } \\
\text { intellectual content }\end{array}$ \\
\hline $\begin{array}{l}\text { Martin M. } \\
\text { Brown, FRCP }\end{array}$ & $\begin{array}{l}\text { Stroke Research Centre, } \\
\text { University College } \\
\text { London, Institute of } \\
\text { Neurology, UK }\end{array}$ & $\begin{array}{l}\text { Acquisition of data, } \\
\text { revised the manuscript for } \\
\text { intellectual content }\end{array}$ \\
\hline $\begin{array}{l}\text { Joan Grieve, } \\
\text { MD }\end{array}$ & $\begin{array}{l}\text { Department of } \\
\text { Neurosurgery, The } \\
\text { National Hospital of } \\
\text { Neurology and } \\
\text { Neurosurgery, London, } \\
\text { UK }\end{array}$ & $\begin{array}{l}\text { Acquisition of data, } \\
\text { revised the manuscript for } \\
\text { intellectual content }\end{array}$ \\
\hline $\begin{array}{l}\text { David J. } \\
\text { Werring, PhD, } \\
\text { FRCP }\end{array}$ & $\begin{array}{l}\text { Stroke Research Centre, } \\
\text { University College } \\
\text { London, Institute of } \\
\text { Neurology, UK }\end{array}$ & $\begin{array}{l}\text { Designed and } \\
\text { conceptualized study, } \\
\text { interpreted the data, } \\
\text { revised the manuscript for } \\
\text { intellectual content }\end{array}$ \\
\hline $\begin{array}{l}\text { Henry } \\
\text { Houlden, PhD, } \\
\text { FRCP }\end{array}$ & $\begin{array}{l}\text { Neurogenetics } \\
\text { Laboratory, The National } \\
\text { Hospital of Neurology and } \\
\text { Neurosurgery, London, } \\
\text { UK }\end{array}$ & $\begin{array}{l}\text { Designed and } \\
\text { conceptualized study, } \\
\text { interpreted the data, } \\
\text { revised the manuscript for } \\
\text { intellectual content }\end{array}$ \\
\hline
\end{tabular}

Appendix 2 Coinvestigators

\begin{tabular}{lll}
\hline Name & Location & Contribution \\
\hline $\begin{array}{l}\text { Gareth } \\
\text { Roberts }\end{array}$ & Royal Preston Hospital & $\begin{array}{l}\text { Recruited } \\
\text { patients }\end{array}$ \\
\hline Timothy Jones & St George's Hospital, London & $\begin{array}{l}\text { Recruited } \\
\text { patients }\end{array}$ \\
\hline
\end{tabular}


Appendix 2 (continued)

\begin{tabular}{|c|c|c|}
\hline Name & Location & Contribution \\
\hline Giles Critchley & Hurstwood Park Neurologic Centre & $\begin{array}{l}\text { Recruited } \\
\text { patients }\end{array}$ \\
\hline $\begin{array}{l}\text { Pankaj } \\
\text { Sharma }\end{array}$ & $\begin{array}{l}\text { Imperial Healthcare, Charing Cross } \\
\text { Hospital, London }\end{array}$ & $\begin{array}{l}\text { Recruited } \\
\text { patients }\end{array}$ \\
\hline $\begin{array}{l}\text { Richard } \\
\text { Nelson }\end{array}$ & Frenchay Hospital, Bristol & $\begin{array}{l}\text { Recruited } \\
\text { patients }\end{array}$ \\
\hline $\begin{array}{l}\text { Peter } \\
\text { Whitfield }\end{array}$ & Derriford Hospital, Plymouth & $\begin{array}{l}\text { Recruited } \\
\text { patients }\end{array}$ \\
\hline Stuart Ross & Leeds General Infirmary & $\begin{array}{l}\text { Recruited } \\
\text { patients }\end{array}$ \\
\hline Hiren Patel & Salford Royal Hospital & $\begin{array}{l}\text { Recruited } \\
\text { patients }\end{array}$ \\
\hline Paul Eldridge & The Walton Centre, Liverpool & $\begin{array}{l}\text { Recruited } \\
\text { patients }\end{array}$ \\
\hline $\begin{array}{l}\text { Kari } \\
\text { Saastamoinen }\end{array}$ & The Royal London Hospital & $\begin{array}{l}\text { Recruited } \\
\text { patients }\end{array}$ \\
\hline Umang Patel & $\begin{array}{l}\text { Sheffield Teaching Hospitals NHS } \\
\text { Trust }\end{array}$ & $\begin{array}{l}\text { Recruited } \\
\text { patients }\end{array}$ \\
\hline $\begin{array}{l}\text { Enas } \\
\text { Lawrance }\end{array}$ & Mayday Hospital, Croydon & $\begin{array}{l}\text { Recruited } \\
\text { patients }\end{array}$ \\
\hline $\begin{array}{l}\text { Subha } \\
\text { Vandabona }\end{array}$ & Mount Gould Hospital, Plymouth & $\begin{array}{l}\text { Recruited } \\
\text { patients }\end{array}$ \\
\hline $\begin{array}{l}\text { David } \\
\text { Mendelow }\end{array}$ & $\begin{array}{l}\text { Newcastle University Hospitals NHS } \\
\text { Trust }\end{array}$ & $\begin{array}{l}\text { Recruited } \\
\text { patients }\end{array}$ \\
\hline Rachel Teal & Oxford Radcliffe Infirmary & $\begin{array}{l}\text { Recruited } \\
\text { patients }\end{array}$ \\
\hline
\end{tabular}

\section{References}

1. Vlak MH, Algra A, Brandenburg R, Rinkel GJ. Prevalence of unruptured intracranial aneurysms, with emphasis on sex, age, comorbidity, country, and time period: a systematic review and meta-analysis. Lancet Neurol 2011;10:626-636.

2. Johnston SC, Selvin S, Gress DR. The burden, trends, and demographics of mortality from subarachnoid hemorrhage. Neurology 1998;50:1413-1418.

3. Suarez JI, Tarr RW, Selman WR. Aneurysmal subarachnoid hemorrhage. New Engl J Med 2006;354:387-396.

4. Kim ST, Brinjikji W, Lanzino G, Kallmes DF. Neurovascular manifestations of connective-tissue diseases: a review. Interv Neuroradiol 2016;22:624-637.

5. Flahault A, Trystram D, Nataf F, et al. Screening for intracranial aneurysms in autosomal dominant polycystic kidney disease is cost-effective. Kidney Int 2018;93: $716-726$.
6. Alg VS, Sofat R, Houlden H, Werring DJ. Genetic risk factors for intracranial aneurysms: a meta-analysis in more than 116,000 individuals. Neurology 2013;80: 2154-2165.

7. Bourcier R, Redon R, Desal H. Genetic investigations on intracranial aneurysm: update and perspectives. J Neuroradiol 2015;42:67-71.

8. Huttunen T, von und zu Fraunberg M, Frosen J, et al. Saccular intracranial aneurysm disease: distribution of site, size, and age suggests different etiologies for aneurysm formation and rupture in 316 familial and 1454 sporadic eastern Finnish patients. Neurosurgery 2010;66:631-638; discussion 638.

9. Oike $\mathrm{Y}$, Ito $\mathrm{Y}, \mathrm{Maekawa} \mathrm{H}$, et al. Angiopoietin-related growth factor (AGF) promotes angiogenesis. Blood 2004;103:3760-3765.

10. Camenisch G, Pisabarro MT, Sherman D, et al. ANGPTL3 stimulates endothelial cell adhesion and migration via integrin alpha vbeta 3 and induces blood vessel formation in vivo. J Biol Chem 2002;277:17281-17290.

11. Le Jan S, Amy C, Cazes A, et al. Angiopoietin-like 4 is a proangiogenic factor produced during ischemia and in conventional renal cell carcinoma. Am J Pathol 2003;162: $1521-1528$.

12. Santulli G. Angiopoietin-like proteins: a comprehensive look. Front Endocrinol 2014; $5: 4$.

13. Bourcier R, Le Scouarnec S, Bonnaud S, et al. Rare coding variants in ANGPTL6 are associated with familial forms of intracranial aneurysm. Am J Hum Genet 2018;102: 133-141.

14. Hostettler IC, Alg VS, Shahi N, et al. Characteristics of unruptured compared to ruptured intracranial aneurysms: a multicenter case-control study. Neurosurgery 2017.

15. Lek M, Karczewski KJ, Minikel EV, et al. Analysis of protein-coding genetic variation in 60,706 humans. Nature 2016;536:285-291.

16. Hato $\mathrm{T}, \mathrm{Tabata} \mathrm{M}$, Oike $\mathrm{Y}$. The role of angiopoietin-like proteins in angiogenesis and metabolism. Trends Cardiovasc Med 2008;18:6-14.

17. Hendricks AE, Bochukova EG, Marenne G, et al. Rare variant analysis of human and rodent obesity genes in individuals with severe childhood obesity. Sci Rep 2017;7: 4394.

18. Burkhard P, Stetefeld J, Strelkov SV. Coiled coils: a highly versatile protein folding motif. Trends Cell Biol 2001;11:82-88.

19. Ono $\mathrm{M}$, Shimizugawa $\mathrm{T}$, Shimamura $\mathrm{M}$, et al. Protein region important for regulation of lipid metabolism in angiopoietin-like 3 (ANGPTL3): ANGPTL3 is cleaved and activated in vivo. J Biol Chem 2003;278:41804-41809.

20. Shimamura M, Matsuda M, Yasumo H, et al. Angiopoietin-like protein3 regulates plasma HDL cholesterol through suppression of endothelial lipase. Arteriosclerosis Thromb Vasc Biol 2007;27:366-372.

21. Wang Y, Lam KS, Lam JB, et al. Overexpression of angiopoietin-like protein 4 alters mitochondria activities and modulates methionine metabolic cycle in the liver tissues of $\mathrm{db} / \mathrm{db}$ diabetic mice. Mol Endocrinol 2007;21:972-986.

22. Oike Y, Akao M, Yasunaga K, et al. Angiopoietin-related growth factor antagonizes obesity and insulin resistance. Nat Med 2005;11:400-408.

23. Yan J, Hitomi T, Takenaka K, et al. Genetic study of intracranial aneurysms. Stroke 2015;46:620-626.

24. Zhang J, Claterbuck RE. Molecular genetics of human intracranial aneurysms. Int J Stroke 2008;3:272-287.

25. PCNT point mutations and familial intracranial aneurysms. Neurology 2019;93:231.

26. Hamilton A, Tetreault M, Dyment DA, et al. Concordance between whole-exome sequencing and clinical Sanger sequencing: implications for patient care. Mol Genet Genomic Med 2016;4:504-512.

27. Kelley LA, Mezulis S, Yates CM, Wass MN, Sternberg MJ. The Phyre2 web portal for protein modeling, prediction and analysis. Nat Protoc 2015;10:845-858.

28. Kollman JM, Pandi L, Sawaya MR, Riley M, Doolittle RF. Crystal structure of human fibrinogen. Biochemistry 2009;48:3877-3886. 


\section{Neurology}

\section{ANGPTL6 Genetic Variants Are an Underlying Cause of Familial Intracranial Aneurysms \\ Isabel C. Hostettler, Benjamin O'Callaghan, Enrico Bugiardini, et al.}

Neurology 2021;96;e947-e955 Published Online before print October 26, 2020

DOI 10.1212/WNL.0000000000011125

This information is current as of October 26, 2020

\section{Updated Information \&} Services

References

Subspecialty Collections

Permissions \& Licensing

Reprints including high resolution figures, can be found at: http://n.neurology.org/content/96/6/e947.full

This article cites 27 articles, 8 of which you can access for free at: http://n.neurology.org/content/96/6/e947.full\#ref-list-1

This article, along with others on similar topics, appears in the following collection(s):

\section{All Genetics}

http://n.neurology.org/cgi/collection/all_genetics

Stroke prevention

http://n.neurology.org/cgi/collection/stroke_prevention

Subarachnoid hemorrhage

http://n.neurology.org/cgi/collection/subarachnoid_hemorrhage

Information about reproducing this article in parts (figures,tables) or in its entirety can be found online at:

http://www.neurology.org/about/about_the_journal\#permissions

Information about ordering reprints can be found online:

http://n.neurology.org/subscribers/advertise

Neurology ${ }^{\circledR}$ is the official journal of the American Academy of Neurology. Published continuously since 1951, it is now a weekly with 48 issues per year. Copyright Copyright ( 2020 The Author(s). Published by Wolters Kluwer Health, Inc. on behalf of the American Academy of Neurology.. All rights reserved. Print ISSN: 0028-3878. Online ISSN: 1526-632X.

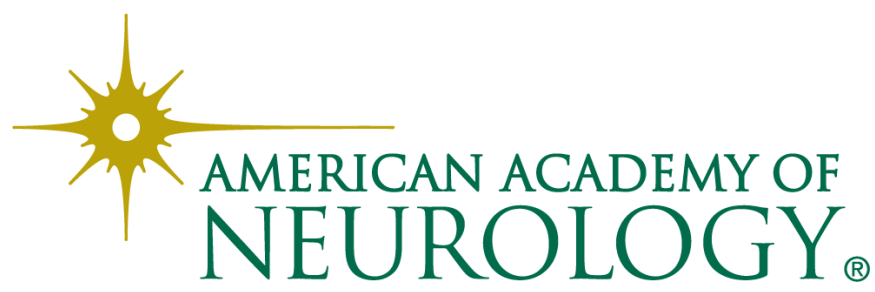

